\title{
Standardising Kven: Participation and the role of users
}

\section{Introduction}

Norway's ratification of the European Charter for Regional or Minority Languages and the Framework Convention for the Protection of National Minorities has had a profound impact on Norwegian minority language policies. This article focuses on how the ratification of the European Charter for Regional or Minority Languages in particular has changed the status of Kven, a Finnic language spoken by a minority in Northern Norway. Initially, though covered by the Charter, the Kven language was regarded as a dialect of Finnish and referred to as Kven/Finnish, but in April 2005 Kven was recognised as a language and not just a dialect of Finnish. This article investigates to what extent this recognition has influenced the situation of the Kven language by discussing what effects the status of Kven as a separate language has had on practical policies, such as standardisation.

The aims of this article are to give an overview of Norwegian minority language policies from a historical and contemporary perspective, concentrating on the Kven language. The primary focus is on the participation and role of users in the standardisation of Kven. In the following, I will give an outline of the history of the Kven people and the Norwegian policies of assimilation and discuss to what extent the ratification of the European Charter for Regional or Minority Languages has influenced Norwegian language policies towards the Kven language. I outline how various user groups were included in the standardisation process in order to create a standard that would be seen as legitimate by Kven speakers. In the final section of the article, I analyse how a Kven speaker relates to the idea of a Kven standard when interviewed and how her positioning changes when she reads a text in Kven for the first time. The article concludes by suggesting that a multifaceted methodological approach is called for when analysing complex social processes such as minority language standardisation.

\section{Historical background}

Norway is often described as a monolingual country (though with two written standards - Nynorsk and Bokmål), apart from a Sámi minority in the North. Large parts of Northern Norway are bi - or trilingual; the languages in contact being Norwegian, Sámi and Finnish. The Sámis are an indigenous group who live in the 
northern parts of Norway, Sweden, Finland and Russia, and they speak a FinnoUgric language related to Finnish. The Arctic areas have been multilingual for as long as we have written records, and people have made seasonal travels between the inland and the coast for fishing, trading, etc. for centuries. From the beginning of the $17^{\text {th }}$ century, Finnic-speaking peoples from the Northern parts of today's Finland and Sweden settled along the coasts of the two northernmost counties of Norway; many of them settled before the final national frontiers were drawn (Guttormsen 1998; Saressalo 1998). Today, this group of people and their descendants are called Kven, but some prefer the term finskætta 'of Finnish descent'. Before the period of national romanticism, the Kven were regarded as a valuable contribution to the northern Norwegian financial system as they were experienced farmers, foresters and worked in the mines. During the $18^{\text {th }}$ century and the first half of the $19^{\text {th }}$ century, children were allowed to speak Kven ${ }^{1}$ and Sámi at school and some tuition was offered in Finnish. This attitude changed when the idea of Norway as an independent nation emerges in the $19^{\text {th }}$ century at the height of European national romanticism. Norway was in a union with Denmark until 1814, and then with Sweden from 1814 until Norway's independence in 1905. Thus Norway is a fairly young nation state. Nationalism in Norway is influenced by German nationalism: the nation was defined in terms of ethnicity and language was the outward sign of ethnicity (cf. Cabanel 1997), and thus, language became the defining criterion of the nation. The last part of the Finnish settlement coincided with the emergence of Norway as a nation state. The idea of 'one nation - one language' was a key element in this process, and in the period from 1840-1960, the official political goal was to "Norwegianise" the minorities in the north (Eriksen and Niemi 1981, 1994; Saressalo 1998; Seppola 1996; Pietikäinen et al. 2010; Lane 2011).

The Kven went through a period of substantial linguistic oppression. From 1850 the official Norwegian goal was to make the local population shift to Norwegian. In 1880 new guidelines for the schools were issued, and the use of Finnish and Sámi was forbidden. This remained the official Norwegian policy until 1959. During this period of Norwegianisation, both the Kven and Sámi minorities suffered linguistic oppression. Speaking Kven was considered a great shame, so the Kven tried to speak Norwegian as best they could, but their Norwegian was not 'proper' Norwegian. Thus they were in a position of double shame: Their mother tongue was worthless, and they could only try to replace it with a foreign language they did not master (Lane 2011: 67). Kven and Sámi children were not allowed to use their languages at school, and in some cases children were beaten if they used their mother tongue (Seppola 1996). Parents were encouraged to speak Norwegian to their children, and the teachers would visit parents and advise them not to speak Finnish to their chil-

1 Since the $16^{\text {th }}$ century terms such as Finn, Finnish, Kven and Kainu have been used to refer to this group of people, see Niemi 1991 for a discussion. 
dren. If the teachers' efforts were successful, they were awarded a salary increase. Boarding schools where the use of Finnish and Sámi was strictly forbidden were established to ensure a Norwegian environment. In 1940 there were 21 such boarding schools in the two northernmost counties of Norway where the total population was estimated to be approximately 100 000. Niemi (1997: 73, quoted in Huss 1999: 89) describes the role of the school in the following manner: "the main battle was over language and identity, the main battlefield was the classroom, and the rank and file soldiers were the teachers". Churches were built in the traditional Norwegian style, and only the Norwegian language was used. Until 1964 only people who could prove that they could speak Norwegian were allowed to buy land (Eriksen and Niemi 1981), and Norwegian farmers from the south were given land in the Northern areas to ensure a Norwegian presence (Lane 2011: 59-60). People who received mail, newspapers or books from Finland were under surveillance by Norwegian authorities because the Norwegian authorities feared that Finland or Russia might use the Kven to gain influence in the North. The rights to this area had been disputed earlier; in periods the inhabitants paid taxes to three nations: Norway, Sweden and Russia.

\section{The Kven - immigrants or a traditional part of Norwegian society?}

When the idea of Norway as a nation state materialised during the $19^{\text {th }}$ century, the attitude towards the northern minorities changed; now they were described as 'foreign nations', and particularly the Kven were regarded with suspicion (Lane 2011). The borders between Norway and Finland-Russia had recently been established and the Kvens' loyalty to the Norwegian nation was questioned as they had a mother tongue other than Norwegian and many of them did not speak Norwegian at all. Thus, Norwegian authorities feared that Finland would use the Kven as a 'bridge' to lay claims on this part of Norway, and this was referred to as the 'Finnish danger' (Eriksen and Niemi 1989; Niemi 2001). Thus, during the $19^{\text {th }}$ century the image of the Kven as a national group was transformed into seeing them as immigrants. This view prevailed until the 1990s: at a seminar on Kven research and politics an advisor for the Norwegian Government stated that he did "not care whether the Kven had come during the $16^{\text {th }}$ century or the $19^{\text {th }}$ century. The Kven were immigrants because this was what the Norwegian Government had decided" (quoted in Megard 1999:83). This statement followed a presentation in which the advisor had argued that the Kven were immigrants and that their status and rights therefore were comparable to those of other immigrant groups (Lane 2011: 62).

The consequences of the Norwegianisation process were strengthened after the Second World War. When the German Army retreated during the autumn of 1944, 
they used the tactics of the scorched earth and burned houses, barns, stables, boats, bridges, only some churches were left behind. After the war money for rebuilding the region was provided by the Norwegian state, and in order to receive money one had to apply in Norwegian. Prefabricated houses designed by architects from southern Norway were built, and most visible signs of the previous building style and the material aspects of the Kven culture were gone. The period after WWII was characterised by the idea of Scandinavian social democracy: The Norwegian Welfare State was founded on the idea of equality and homogeneity. Knowledge of the Norwegian language was the key factor of success as forms and applications had to be completed in Norwegian, and a successful application brought privileges. Thus, knowledge of Norwegian became linked to success, privileges and modernity (Lane 2011: 60).

In 1959 the ban on the use of Finnish and Sami in the schools was removed, but in many villages children were still punished if they spoke their mother tongue. During the 1970s, the Sámis demanded recognition and then got recognised as an indigenous people, and slowly they gained right to Sámi tuition, Sámi became an official language and the Sámi Parliament was established (Pietikäinen et al. 2010, Lane and Makihara in press). The Sami cultural and linguistic awakening and recognition by the nation state seem to have influenced the Kven awakening to some extent: "if they could do this, so can we". For the Kven, initially most of the efforts centred on language; the Kven communities were at advanced stages of language shift, and they wanted more linguistic rights.

In 1998 the Norwegian Parliament ratified The European Framework Convention for Protection of National Minorities and the Kven are now a national minority. Finnish got status as a second language in the schools, and pupils in the Northern area could choose to study Finnish instead of one of the two official Norwegian written standards. Currently more than 582 pupils have opted to study Finnish as a second language (primary school level). The number of pupils has declined, and a report gives three primary reasons: the pupils study Finnish when their class mates have other subjects and therefore find it difficult to catch up, progression is slow, and some pupils state that they find the subject difficult (Nygaard and Bro 2015). Kven gained recognition as a national minority language in 2005, but most of the schools still teach standard Finnish as there is a lack of text books in Kven. Descriptions of the Kven as immigrants or descendants of immigrants is prevalent in numerous government publications, even after Norway ratified the Framework Convention for the Protection of National Minorities and the European Charter for Regional or Minority Languages ${ }^{2}$.

2 The Charter entered into force in Norway in 1998 and protects and promotes Sami, Kven/Finnish, Romanes and Romani 


\section{Kven - language or dialect?}

There are no clear linguistic criteria for telling dialects and languages apart. The Kven language can be considered to be a separate language from Finnish because it has been spoken for centuries in Northern Norway separated by state borders from (the rest of) the Finnic language community in what today is Finland and Northern Sweden (Hyltenstam and Milani 2003). When the Kven migrated they brought their language, which developed separately from the Finnish spoken in Finland. During the $19^{\text {th }}$ century language planning took place in Finland, as in many other European countries, and the political situation in Norway did not encourage contact with Finland. In Finland, Finnish was given official status in 1863 and was developed into a language of education and administration. Vocabulary and structures from the Eastern Finnish dialects were included, and neologisms were created in order to replace Swedish loanwords (Latomaa/Nuolijärvi 2005). These standardisation efforts influenced the Finnish dialects in Finland, whereas the Kven had left before this standardisation took place. Because the Kven were not in Finland during the standardisation process, their language developed differently, particularly in terms of vocabulary. The largest difference between Kven and standard Finnish is lexical due to old Swedish borrowings that have been retained in Kven and newer borrowings from Norwegian. Kven and Finnish are mutually intelligible, though Finnish speakers understand Kven better than Kven speakers understand Finnish because Finns learn Swedish in school and therefore understand Swedish and Norwegian borrowings in Kven, whereas Kven speakers in most cases do not understand the Finnish equivalents of these borrowings. Self-identification is also one of the criteria for the language - dialect distinction: the Kven speakers identify themselves as Norwegian and not Finnish (Hyltenstam/Milani 2003; Lane 2009).

As a part of the monitoring cycle the Committee of Ministers at the European Council repeatedly pointed out "various measures undertaken by the authorities designed to protect and promote Kven/Finnish do not distinguish between Kven and Finnish. For this reason the Committee has found it difficult to evaluate the exact measures carried out by the Norwegian authorities vis-à-vis the Kven language" (ECRML 2001: 9). The reason given by the Committee of Ministers for the need of clarification of the status of the Kven language was to improve the situation for the language in conformity with Part II of the Charter ${ }^{3}$. They also stressed the importance of reaching a conclusion quickly as unnecessary delay may have grave

3 The Charter is divided into two main parts, a general one containing the principles applicable to all the Parties and all regional or minority languages (Part II), and a second part which lays down specific practical commitments which may vary according to the state and the language (Part III). http://www.coe.int/t/e/legal_affairs/local_and_regional_democracy/regional_or_minority_langu ages/1_The_Charter/_summary.asp 
consequences for the Kven language, and they stressed the need for urgent and resolute action. The recommendation of the Council of Europe was to rapidly solve the situation of the Kven/Finnish language and consult with the representatives of the Kven on this matter before decision was made (ECRML 2001; Lane 2011).

As a consequence of this, the Norwegian government commissioned a report on the status of Kven carried out by Kenneth Hyltenstam, Professor at the University of Stockholm, and the report concluded that based on linguistic and socio-political criteria Kven should be regarded as a language and not a dialect of Finnish (Hyltenstam/Milani 2003). The report was distributed to relevant organisations that were invited to comment. This sparked a lively debate in local and national media which, basically focussed on two themes: whether Kven should be regarded as a language in its own right and not a dialect of Finnish, and whether it would be desirable to name such a variety Kven as this used to be a stigmatised term. Some maintain that one should continue using Finnish as the written language, while referring to the local spoken varieties as Kven. Others reject the term Kven totally because of negative connotations, and some of these have started employing the term "Kainu" instead of Kven. Kainu is a Finnish word which refers to the northern area of the Gulf of Bothnia and it has been claimed that it has the same etymological root as the Norse hvein - low, wet ground. However, it is not likely that the Norse hvein developed into kven as this sound change is not attested in any other words during this period (Lane/Theil 2003). Still, the term Kainu for some is an alternative both to the term Kven if it is seen as stigmatised and the term Finnish that is associated with the modern nation state of Finland. In many ways this debate echoes the discussion of the early 90s when the term Kven used as a name for the group of people was debated (Niemi 1991).

After assessing comments from relevant parties, including the Kven Association, the Ministry of Culture and Church Affairs issued a press release April 242005 containing the following message: "The Ministry of Culture and Church Affairs proposes: Kven is to be recognized as a separate language and to be protected under Part II of the European Charter for Regional or Minority Languages”. Thus Norway recognised Kven as a language primarily as a consequence of the monitoring system which followed the ratification of the Charter, and almost all the measures taken by Norwegian authorities to promote and develop the Kven language have arisen because of influence from the Council of Europe.

\section{The Kven speakers' language attitudes}

As outlined above, the school was the major arena for bringing in the Norwegian culture and language as the use of Kven was forbidden by law. When measured against standard Finnish, they felt that their Kven language fell short because of 
lexical and grammatical differences. But they could not meet the standard of Norwegian either as Norwegian was not their mother tongue. Those who grew up speaking Kven and learnt Norwegian as a second language in the school, in spite of speaking fluent Kven and using it in almost all domains of their everyday lives, felt that their linguistic skills were inadequate. During the period from 1996 to 2008, I have interviewed 20 people from my home community and also recorded everyday conversations. I have also employed field assistants who in 2008 and 2009 interviewed 32 inhabitants from my village, and these data are available to other researchers through the Ruija corpus at the University of Oslo ${ }^{4}$.

The following example illustrates the feeling of shame and double inferiority many Kven speakers have experienced (Lane 2010: 71). Ida grew up in a Kvenspeaking family, she spoke Kven with her parents, but like the majority of people from my home community, she spoke Norwegian with her children.

\section{Example 15}

Ida:

før sa vi at (.) ja mamma og pappa sa ikke kan du norsk og ikke kan du finsk (.) du e sånn [5 second pause] du kan ingen ting du (.) kan ingenting ordentlig (.) språkforderva

before we said that (.) yeah Mum and Dad said you can't speak Norwegian, nor can you speak Finnish (.) you're like [5 second pause] you don't know anything (.) don't know anything properly (.) linguistically rotten

Lane (2010) shows how the feeling of shame and inferiority has been passed on to subsequent generations to the extent that such feelings may become part of people's habitus, self-perception and general world-view. Through the encounter with the Norwegian officialdom mainly through the educational system, the mother tongue of the Kven was devalued. Thus, many Kven came to see their language as a language not worth keeping and chose not to pass it on to their children. There are many stories about traumatic encounters with the Norwegian school and the feeling of helplessness and inadequacy of those who started school without knowing Norwegian. One of the Kven speakers I interviewed expressed that meeting the Norwegian school without a language was a burden she did not want to place on her children, and therefore she chose to speak Norwegian only even though this was her second language (Lane 2010: 65).

4 https://www.hf.uio.no/iln/english/about/organization/text-laboratory/projects/ruija/ ruija.html

5 Transcription key:

(.) pause

.h in-breath 
In the example above Ida uses the adverb før 'before' and thereby situates the story in the past, implying that the situation is different now by establishing a time trajectory where the comment is situated in the past. This particular interview was conducted in 2004, and newer interviews also show this tendency to question and evaluate decisions made in the past. In general, there is a far more positive attitude to and identification with Kven language and culture.

\section{The Ratification of the European Charter for Regional or Minority Languages and its impact on the status of Kven Language}

The ratification of the European Charter for Regional or Minority Languages has had a profound impact on the status of the Kven language. (Lane 2011) The ratification of the Charter and the monitoring of Norway's obligations have had consequences for Norway's language policies towards the national minorities, both because of the concrete actions Norway has committed itself to carry out, but also because there are some important structural changes which have followed the ratification. Prior to the ratification the Norwegian government was the only authority/institution the minority language speakers and their interest organisations could address, as illustrated in the following figure:

Government

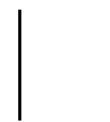

(Minority language organisations)

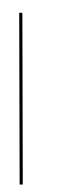

Grass root level

Figure 1: Situation prior to the ratification of the European Charter for the protection of regional or minority languages (Based on Huss and Lane 2006)

After the ratification both the minority language users, their representatives, researchers and others got the possibility to address the Council of Europe directly, facilitated by the monitoring mechanism. Therefore, they became less dependent on the minority language policies on the national level as the monitoring process pro- 
vided the national and regional minorities with the possibility of bypassing the national level (see Huss 2008) as illustrated in Figure 2.

Simultaneously this process has also strengthened the dialogue between Norwegian authorities and representatives for the national minorities. As a result of the recommendations from the Council of Europe there are now annual meetings between Norwegian authorities and representatives for the minority languages covered by the Framework Convention and also smaller-scale meetings and seminars, and more information, both to the minority groups themselves, and about the national minorities and their languages aimed at the society at large.

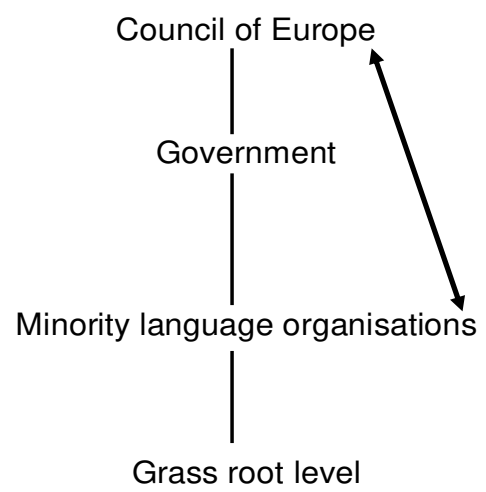

Figure 2: After the ratification of the European Charter for the protection of regional or minority languages (Based on Huss and Lane 2006)

Prior to the ratification of the Charter the dialog only took place between the Kven and representatives of the Norwegian Government, but after the ratification the Council of Europe has entered the arena and empowered the Kven through the close monitoring cycle. This has led to more extensive contact between the representatives of the Kven and the national authorities. Thus, the ratification of the European Charter for Regional or Minority Languages and Framework Convention for the Protection of National Minorities has considerably improved the situation and protection of the Kven language and has also strengthened revitalisation of Kven culture. Currently, there is an increasing interest in the Kven language and culture both amongst the Kven themselves and also within the majority population. Thus, the Kven who have been described as "Norway's silent minority” (Mikkelsen 2005) have found a voice through the ratification of these European treaties.

The acceptance of Kven as a language and not primarily a dialect of Finnish gave Kven a new status, including it as a part of the Norwegian cultural heritage. Thus, there is acceptance at two levels, linguistically and culturally. This shows how the ratification of a Charter on the European level may have an impact on the recog- 
nition and inclusion of a minority language on the national level. However, as repeatedly pointed out by the Council of Europe, Norwegian minority language policies have been characterised by a range of isolated actions, but there is a lack of an encompassing plan for the protection and promotion of the languages protected by Part II of the Charter. A reason for this might be the that the Norwegian authorities seem to regard Part II of the Charter as an expression of goodwill, but not a legally binding treaty as the addition to Norway's Third report, page 4 states: "protection under Part II entails commitments, but no legally binding obligations". Part II of the Charter outlines a minimum level of protection, and the Committee of Experts point out that a Party is obliged to apply the objections and principles set out by the Charter to all the regional or minority languages on its territory (ECML 2005: 7). These are measures such as ensuring that there is research on and some tuition in minority languages, media broadcasts in the minority languages, provision of facilities enabling non-speakers of a minority language living in the area where it is used to learn it etc. In their 2015 report, the Committee of Experts point out that:

there is no structured policy for the protection and promotion of Kven. A comprehensive action plan should be developed and implemented, in co-operation between the authorities and the speakers. In the short term, priority should be given to establishing an offer in Kven at preschool level and to strengthening its presence in broadcasting

However, if Norway regards Part II of the Charter only as an expression of good intentions and not a legally binding treaty, the protection for Kven and the other languages covered by Part II only is not as strong as one would expect when reading the text of the Charter. If this is the case, then the recognition of Kven as a language in its own right is a change in name only: Kven has been recognised as a language, but the possibilities for Kven people to reclaim or learn to read and write Kven have not increased substantially. Some financial resources have been allocated to a Kven cultural centre and to establish a Kven language council. However, this funding is not sufficient to develop a comprehensive written standard for the Kven language which in turn makes it almost impossible to produce teaching materials for Kven. As a result, Kven is still regarded as a part of the tuition of standard Finnish and the textbook used in the schools teach standard Finnish. Nevertheless, the monitoring cycle empowers the national minorities through a larger degree of influence, which in turn might lead to the Norwegian authorities redefining their interpretation of Part II of the Charter or giving more language protection under Part III.

The case of the Kven language demonstrates how changes in legislation (i.e. Norway's ratification of the European Charter for the Protection of regional or Minority Languages and the European Framework Convention for the Protection of National Minorities) have changed both the nation's view of minority groups and also the minority groups' view of themselves and their language. In addition to influencing and changing minority language policies, the recognition of historical 
minorities and their languages have recast the view of the nation state as Norway now sees its historical diversity as a part of the nation's cultural heritage.

\section{Kven Language Body: The Kven Language Council and The Kven Language Board}

Norway's ratification of the European Charter for Regional or Minority Languages in 1998 led to the recognition of Kven as a language in 2005. The Norwegian Government allocated some funds for the standardisation of Kven (Lane 2011, 2015), and in 2007, the process of developing a written standard for Kven started. The board of the Kven Institute (a state financed centre for Kven language and culture) elected five linguists as representatives to the Kven Language Council. Four of the members were linguists in academic positions, whereas the fifth member had been actively involved in teaching both Finnish and Kven. The council had an advisory role, and their mandate was to outline the principles for the standardisation of Kven. Their recommendations were then presented to an executive board, the Kven Language Board, whose members represented various domains seen as important to the Kven language such as education, media, and religious organisations (Lane 2015).

Table 1: The Kven Language Council and Board

\begin{tabular}{lll}
\hline & Kven Language Council & Kven Language Board \\
\hline Members & Linguists & $\begin{array}{l}\text { Representatives for domains of use } \\
\text { of Kven }\end{array}$ \\
Tasks & Mapping linguistic variation & $\begin{array}{l}\text { Provide feedback to the Kven Lan- } \\
\text { guage Council }\end{array}$ \\
& $\begin{array}{l}\text { Outlining principles for standardi- } \\
\text { sation }\end{array}$ & \\
Function & Advisory & Executive \\
\hline
\end{tabular}

The vision and hence mandate for the Kven Language Body was to ensure participation of Kven speakers and to develop a standard the speakers themselves would want to use. Standardisation, and minority language standardisation in particular, is a complicated and often contradictory process (Gal 2006; Lane 2011; 2015), consisting of shifting, interlinked and at times competing top-down and bottom-up processes (Darquennes and Vandenbussche 2015).

The standardisation of Kven provides an illustrative example: there had been a strong grassroots movement lobbying for the status of Kven to get clarified, after Kven got recognised as a language in its own right and not just a dialect of Finnish, 
the Norwegian government gave the Kven Institute funding and the mandate to initiate the work of standardising Kven, and then the members of the Kven Language Body were appointed by the Kven institute. The aim was to, through a process of participation, establish a standard that Kven-speakers in various regions would identify with and use - hence, a standard that would be seen as both legitimate and authentic. The standard was seen as a prerequisite for the teaching of Kven in the educational system so that new speakers could have the opportunity to learn Kven and also as means for traditional speakers to write their language. Hence, the degree of variation became a central concern for the language council. A large degree of variation was seen as essential if those who speak or understand Kven were to identify with and accept the standard, whereas a standard with less variation might be easier to master for new speakers who would learn Kven through education. Norway has been characterised as particularly tolerant of variation (Trudgill 2002), and Norwegian has two written standards - Bokmål and Nynorsk (Vikør 2007), each with a large degree of variation. (Røyneland 2009). With this backdrop, it is not surprising the Kven Language Council and Language Board were in agreement on a standard encompassing variation and including forms from a range of Kven dialects, and in a report written by the director of the Kven Language Council, the parallel to the variation in Bokmål and Nynorsk is explicitly mentioned (Andreassen 2009), see also Lane 2015.

The linguists on the Kven Language Council were faced with the tasks of mapping phonological, morphological and syntactic patterns in Kven dialects, outlining similarities between Kven, Meänkieli (a closely related minority language spoken in Northern Sweden) and Standard Finnish, and then presenting subsets of the grammatical system to the Language Board for them to make the final decisions. The members of the Language Board were not trained linguists, though some of the members had studied Standard Finnish. The solution therefore was to use texts to exemplify the various sets grammatical patterns. Three texts were transcribed according to the following criteria: 1) as close to Standard Finnish as possible, 2) 3) as different from Standard Finnish as possible, 4) close to Meänkieli, 5) compromise variety including phonological and morphological patterns from many Kven dialects or 6) a version building on the dialect spoken in Børselv-Pyssyjoki, a village in the western part of the Kven area. The reason for the latter option was that the majority of the (very few) texts that up to this point had been written in a Kven variety had been produced by authors from this village. These texts had been used as materials for developing the first course in Kven offered at the University of Tromsø from 2006.

For each subsection of the grammar, the language council mapped variation according to the varieties listed above with example texts showing how the written texts would look like according to the various options. Based on this, the Kven Language Board decided that preference should be given to patterns found in several Kven dialects, while allowing for some geographical variation (see Lane 2015 for 
discussion of this process). The involvement of minority language speakers was intended to facilitate democracy and also empower the language users themselves through their participation in the decision-making process, thus a process very much in line with the intentions underlying the Charter.

The Kven Language Council and Board's aim when outlining the final principles for the standardisation of Kven was a standard founded in the spectrum of Kven dialects while also prioritising forms that would not impede understanding of Meänkieli and Standard Finnish, the Finnic languages of the neighbouring countries. After the Council's final recommendations for the standardisation of Kven had been approved by the Board in April 2010, the Council's period officially terminated, though the Board's mandate was to ensure that a descriptive grammar of Kven was finalised and contribute to the production of a grammar to be used in schools. In December 2014 a Kven grammar was published. The grammar was written by Eira Söderholm who was one of the members of the Kven Language Council (2007-2010). In 2011 she was commissioned to write the grammar according to the principles approved by the Kven Language Board, while also drawing on teaching materials she had developed for a Kven course at the University of Tromsø. In the foreword to the grammar Söderholm writes that she chose to base the grammar on the majority of texts written in Kven and in particular the novels written by an the author NilsenBørskog from Børselv-Pyssyjoki in the Western Kven dialectal area (in reality favouring patterns close to the Børselv-Pyssyjoki dialect), while also giving preference to forms found in other Kven dialects. In general the grammar was well received and many expressed that having a grammar would facilitate learning Kven and that this also had a strong symbolic value, particularly as this was a state-financed and supported endeavour. However, there were also some negative reactions as the grammar in reality relies primarily on one Western Kven dialect, leading to Kvenspeakers in the Eastern area voicing concern that their varieties were not sufficiently taken into account. Though the Kven language body unanimously had voted for the 'compromise strategy' including patterns found in a range of Kven dialects, the pragmatic decision of the grammar writer was to base the grammar primarily on one geographical variety, thus not observing fully the decision made by the language board. The process had been intended to be democratic and participatory, but the final result still was strongly influenced by the choices of the author of the grammar. There seem to be two main reasons for the author's choice. One of them is explicitly stated by the author herself in the introduction to the grammar and also in various media interviews: there are four novels written in Kven, all by the same author from Børselv-Pyssyjoki, and therefore these could be used as a basis for the Kven written language (while also drawing on the Language Council's work of describing variation in Kven dialects). However, there is an additional reason, namely the lack of adequate financing of the standardisation process. The members of the Kven Language Council and Language Board were reimbursed for their participation in meetings, including a nominal amount for preparation. Language documentation and 
mapping dialectal variation are extremely time-consuming processes, and none of the members were employed to work on such a project. The author of the grammar was also only offered a modest honorarium, and therefore it is understandable that her decisions were grounded in pragmatic reasons. Such decisions are not uncommon when minority languages are standardised: due to limited and even insufficient financing, the actors involved make do with the resources they have at their disposal.

\section{How do users relate to the standard?}

A written standard, like any other form of technology, is not neutral. The choices made by those who are involved in the design and production of standards both set constraints on likely future actions of users and open up scope for future actions (Lane 2015). Thus, a text can be seen as the material outcome of a standardisation process and a result of a chain of actions made by several social actors. In the case of Kven, such actors range from linguists writing academic articles and theses about grammatical aspects of Kven, field assistants interviewing Kven speakers, members of the Kven language body, the Kven Institute and authors of books, stories, poems and also the author of the Kven grammar.

In the remainder of this article I will investigate the relationship between the standard and the user by analysing how speakers position themselves when they read texts in their mother tongue for the first time. As a part of a larger project Standardising Minority Languages, 18 Kven-speakers were filmed when reading texts in Kven for the first time. For most of these speakers Kven is their first or one of their first languages. They are all bilingual in Norwegian and Kven, and some from the Western area are trilingual (Kven, Sámi and Norwegian). The participants were interviewed by my field assistant about how they felt about a written language being developed for Kven. They first read a children's story written by the author Agnes Eriksen from Børselv-Pyssyjoki, thus, in a variety close to the Kven grammar, and then another text written in a variety close to their own dialect. I have chosen to focus on the Eastern area for two reasons: the Kven speakers in this area have been described as being more ambivalent to developing a written standard for Kven, and as the grammar of Kven draws primarily on the Western varieties, I wished to look at how speakers from the Eastern area would react when reading a text in the standardised version of Kven. A main finding from this study is that those who express a negative or ambivalent attitude to the standardisation of Kven when interviewed generally reflect on their experience of reading Kven in a very positive manner (Lane 2015). Reasons for this could be that they have heard that the standard is 'BørselvKven' and influenced by Sámi or that it is not 'a proper language'. However, compared to standard Finnish, the Kven written standard is considerably closer to their 
dialect, and they seem to perceive the text as familiar and easy to read and understand.

As the aim of this article is to investigate how speakers of the Eastern Kven dialects relate to the proposed standard, I will analyse how a Kven speaker from my home village in the Eastern area reacts to the text written in the Western variety close to the standard promoted by the grammar. I chose this person because she clearly represents the patterns briefly outlined above and also because I have interviewed her on other occasions, which allows me to draw on a wide range of observations as an underpinning of the analysis presented here.

In this article, I will focus on a phonological difference that the Kven Language Council and Language Board expected to be salient, namely the use of the interdental fricative /ð/, a phoneme that has been retained by some Kven speakers in Børselv-Pyssyjoki and is used by the writers from this village. For some it is a strong identity marker, and the Language Body therefore decided that 'in language regions where there is a need for additional letters to the Finnish orthography, such as s (alternatively sh) and đ / ð, these may be used'6 (Andreassen 2009). In the Kven grammar the letter $\langle đ\rangle$ is used consistently throughout the book to represent /ð/ even though apart from a few Kven speakers, / $/$ has not been retained in Kven. For those who use /ð/, there is alternation between /t/ and /ð/, whereas the majority of the Kven dialects have alternation between $/ \mathrm{t} /$ and $/ \varnothing / 7$. In written Standard Finnish, the letter $d$ is used, though in spoken language there is variation between $[\emptyset, \mathrm{j}, \mathrm{r}, \mathrm{l}]$. The following table shows the genitive form of the lexeme pöytä - 'table' in Kven dialects and Standard Finnish:

Table 2: Phonological variation in Kven dialects

\begin{tabular}{llll}
\hline & Børselv-Pyssyjoki & Majority of Kven Speakers & Standard Finnish \\
\hline table-GENITIVE & pöyđän & pöyän & pöydän \\
\hline
\end{tabular}

This dental fricative is a phoneme that has been retained from Proto-Finnic by some speakers in Børselv-Pyssyjoki, possibly due to contact with Sámi as BørselvPyssyjoki is a trilingual community. During several fieldwork trips I had met people from my home village in the Eastern part who expressed concern that the Kven written language would be what they referred to as Pyssyjoki Suomi (Børselv-Pyssyjoki Finnish), and many also expressed great ambivalence and even outright negativity to standardising Kven at all. This was also a recurring theme in opinion pieces in

6 My translation

$7 \varnothing$ is used to denote that there is an alternation between a consonant and zero (such as pöytä pöyän) 
local newspapers. I was interested in whether Kven speakers would express different opinions when relating to a text as a material outcome of a standardisation process rather than talking about standardisation on an abstract and disembodied level (Lane 2015, forthcoming).

The text read is the first part of a story in a book by Agnes Eriksen from Pyssyjoki Kummitus ja tähtipoika 'The Ghost and the Star Boy'.

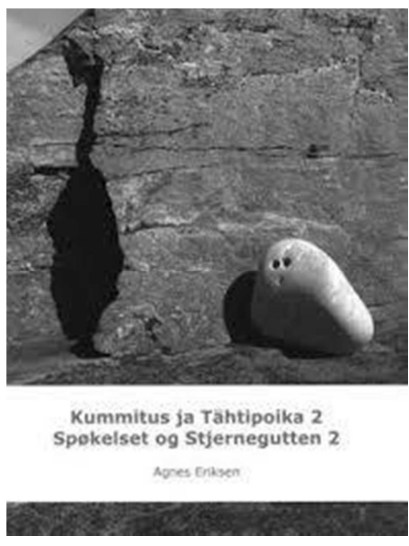

Figure1: Book cover

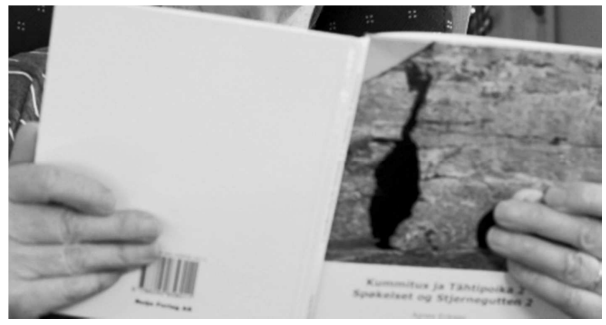

Figure 2: Anna reading
Kaukana pohjaisessa, kauhniin vuonon rannala, oon Kivikylä.

Kesä täälä oon niin ko pitkä päivä, talvi oon niin ko pitkä yö.

Kummitus assuu Kivikylässä.

Hän oon siivo kummitus, joka ei pölättele kethään

Tähtipoika oon Kummituksen paras ystävä.

Hän oon kaukaiselta tähđeltä.

Sinne hän mennee joka talvi.
Far away in the North, by a beautiful fjord, is Stone Village.

The summer here is like a long day, Winter like a long night.

The Ghost lives in the Stone Village.

He's a kind ghost who doesn't frighten

anyone.

The Star Boy is the Ghost's best friend. He comes from a faraway star.

There he goes every winter.

One of the reasons I chose this text to be read is that it is written in the Pyssyjoki dialect and therefore close to the standard used for the Kven language course at the University of Troms $\emptyset$ and the grammar book published in 2014. The author uses the letter $\langle đ>$, as in the word tähđeltä 'star - ablative singular'. I wished to investigate if this unfamiliar letter would alienate Kven speakers from the text and make them see the text as different from their own dialect and also if they would encounter any processing difficulties when reading this word.

The letter $\langle$ đ $>$ is also a part of the Sámi alphabet, and it is familiar from the daily news broadcast in Sámi - Ođđasat. In my home village, some people have stated that the Kven dialect in Børselv-Pyssyjoki in their opinion has traits from Sámi, something that is not seen as positive by everyone. When I ask what makes it sound 
like Sámi, they mention that it sounds Sámi, but they are not able to explain which sounds indicate Sámi influence, perhaps because they lack the vocabulary and concepts for describing phonological differences.

Anna, like Ida quoted earlier in this article, grew up speaking Kven, she spoke Norwegian only to her children, but prefers to speak Kven with people of her own age. She says that she has tried to read Standard Finnish, but that, apart from very short words, she finds this difficult. She reads the text from the book, quite slowly in the beginning and then faster as she gets more familiar with the orthography. When she gets to the sentence with the word tähđeltä (underlined by me in the excerpt above), Anna does encounter some challenges:

hän oon kaukaisella kaukaselma (.) mitä se on (.) tähti ? /looks at interviewer/ (.) onko se oikea /laughs/

he is from far-faraway star (.) what is this (.) star? /looks at interviewer/ (.) is this right /laughs/

Anna misreads the word preceding 'star' twice; in the text she is reading, we find the word kaukaiselta. This is the ablative case of kaukainen 'faraway'. Anna is familiar with this word as this is commonly used in Pykejä, so presumably she would not mispronounce the word twice - first as kaukasella 'faraway-Adessive', followed by kaukaselma. For the latter, the target is unclear as -lma is not a case marker. This is then followed by a pause, and then Anna asks mitä se on 'what this is', while looking at the interviewer and then suggests 'star' in the nominative case - tähti. Anna finishes reading the text, first in Kven and then in Norwegian. Anna has expressed scepticism to developing a Kven standard stating that Kven is like broken Finnish (see Lane 2015 for analysis). However, when asked if she would like to read texts written in Pykeä Finnish, Anna nods and says:

mhm se olisi mukava <smiles> joo .h se olisi mukava oppia omma omma kieli mitä sie ittet puhhut <looks at text on table > mull on viakkea puhua oikea (.) mie en ossa lukkea oike suoma

mhm it would be fun <smiles> yes .h it would be fun to learn your own own language that you yourself speak <looks at text on table > for me it's difficult I can't read proper Finnish

(Lane 2015: 278)

Standardisation always implies leaving something or someone on the outside (Woolgar 1991). As in other forms of technology, users are inscribed and configured through the process of language standardisation. The choice of which forms to be included in the standard inevitably leaves some other forms out, and these decisions are not only founded in linguistic motivations. Those standardising minority languages usually have an intended user, or intended users, in mind, but they are not always aware that they configure the user through their choices. Drawing on Woolgar (1991), we may see users as inscribed in standards through the choices 
made by those involved in standardisation processes. Their choices can be both emancipatory and constraining as they both set constraints on likely future actions of the users and open up scope for future actions (Lane 2015).

When choosing to base the Kven standard primarily on the Western varieties, there is a risk that speakers of other Kven varieties may reject the proposed standard or parts of the standard and thereby position themselves as non-users; they may, for various reasons, oppose, reject or be reluctant to accept standardisation or even get excluded from the standardisation processes (see Lane 2015 for an analysis of nonusers). They may also adapt their behaviour and conform to the inscribed user of the standard and start using features that are not part of their variety. Many Kven speakers who were interviewed or observed move between different positions such as Anna when she expresses a negative attitude to the concept of a Kven standard, but still states that she would like to read texts in 'her language'. Anna perceives the text she is reading as a text written in 'her Finnish', and, while struggling to read the word with an unfamiliar letter in it, finally resolves the conflict by ignoring the written form of the word and reading it in the nominative form to ensure that she grasps the meaning of the text. When Anna is asked what she thinks about developing a written standard for Kven, she expresses an ambivalent attitude to this; while saying that this would be nice, she also say that this is not proper Finnish, and she describes Kven as broken Finnish. Thus, when talking about standardisation in an abstract manner, she expresses reluctance and scepticism. At the same time, she takes a positive attitude to reading text in 'her own language' (Lane 2015), and she identifies strongly with the material outcome of the standardisation process - the text she is reading.

\section{Conclusion}

Developing a standard for a minority language is not a neutral process; this has consequences for the status of the language and how the users relate to the new standard; one risks establishing a standard that the intended users do not identify with. Thus, standardisation which was supposed to empower minority language speakers may create a new form of stigma for those who feel that they cannot live up to the new codified standard. Standardisation is a complex and often contradictory process that may constrain actions of its intended users while at the same time contributing to the agency of social actors (Lane 2015). This tension is reflected in the data analysed in this article as we see that Anna takes positions ranging from rejecting a Kven standard when explicitly asked about her attitudes to such a standard to expressing that she would like more texts when she actually is reading a text in Kven. This also underscores the need for multifaceted methodologies when investigating complex social processes such as minority language standardisation. Com- 
bining sociolinguistic interviews with long-term fieldwork, ethnographically informed approaches and observing social actors when they relate to texts as the material outcome of standardisation processes will contribute to a more in-depth analysis.

\section{References}

Cabanel, P. (1997): La Question Nationale au XXe Siecle. Paris: Découverte.

Darquennes, Jeroen/Vandenbussche, Wim (2015): The standardisation of minority languages introductory remarks. Sociolinguistica 29, 1-16.

ECRML (1999): European Charter for Regional or Minority Languages. Initial Periodical Report, Norway.

ECRML (2001): Comments from the Committee of Experts on Norway's Initial Periodical Report.

ECRML (2002): European Charter for Regional or Minority Languages. Second Periodical Report, Norway.

ECRML (2003): Comments from the Committee of Experts on Norway's Second. Periodical Report.

ECRML (2005): European Charter for Regional or Minority Languages. Third Periodical Report, Norway.

ECRML (2015): Comments from the Committee of Experts on Norway's Sixth Periodical Report.

Eriksen, Knut E./Niemi, Einar (1981): Den Finske Fare: Sikkerhetsproblemer og minoritetspolitikk i Nord 1860-1940. Oslo: Universitetsforlaget.

Gal, Susan (2006): Contradictions of standard language in Europe: Implications for the study of publics and practices. Social Anthropology. 14(2): 163-181.

Guttormsen, Helge (1998): Spor etter eldre kvensk bosetting i Nord-Troms og Finnmark. In: Guttormsen, H. (Ed.) Kvenenes Historie og Kultur. Seminarrapport. Nord-Troms historielag.

Huss, Leena (1999): Reversing language shift in the far North. Linguistic Revitalization in Northern Scandinavia and Finland. Uppsala: Acta Universitatis Upsaliensis, Uppsala University.

Huss, Leena/Lane, Pia (2006): New voices - new visions: Nordic minority language policies in transition. Invited symposium at 2006 Georgetown University Round Table on Languages and Linguistics (GURT): Endangered and Minority Languages and Language Varieties: Defining, Documenting and Developing.

Huss, Leena (2008): Scandinavian minority language policies in transition: The impact of the European Charter for Regional or Minority Languages in Norway and Sweden. In: King, Kendall; Schilling-Estes, Natalie; Fogle, Lyn, Lou; Jia Jackie; Soukup, Barbara. Sustaining Linguistic Diversity. Endangered and Minority Languages and Language Varieties. Washington, DC: Georgetown University Press.

Hyltenstam, Kenneth/Milani, Tomasso (2003): Kvenskans status: Rapport for Kommunal- og Regionaldepartementet og Kultur-og Kirkedepartementet i Norge. Centrum för Tvåspråkighetsforskning, Stockholm University.

Lane, Pia/Theil, Rolf. (2003): Comments on behalf of the University of Oslo on Hyltenstam's Report on the status of the Kven Language.

Lane, Pia (2006): A Tale of Two Towns: A Comparative Study of Language and Culture Contact. PhDThesis. University of Oslo.

Lane, Pia (2010) "We did what we thought was best for our children". A Nexus Analysis of language shift. International Journal of the Sociology of Language. (202), 63-78. 
Lane, Pia (2011): The birth of the Kven language in Norway: Emancipation through state recognition. International Journal of the Sociology of Language (209), 57-74.

Lane, Pia (2015): Minority language standardisation and the role of users. Language Policy, 14, 3, 263-283.

Lane, Pia/Makihara, Miki (in press): Language and indigenous minorities. In: García, Ofelia/ Flores, Nelson/Spotti. Max (Eds.). The Oxford Handbook of Language and Society. Oxford University Press, 299-319.

Latomaa, Sirkku/Nuolijärvi, Pirkko (2005): The language situation in Finland. In: Kaplan, Robert B. and Baldauf, Richard B., Jr. (Eds.). Language Planning and Policy in Europe I: Hungary, Finland and Sweden. Clevedon: Multilingual Matters.

Megard, Bjørn Olav (1999): Kvener og Finskætta. En Undersøkelse av Betegnelsene “Kvener” og "Etterkommere etter Finske Innvandrere" i Politisk Diskurs og i Utforming av Identitetstilknytning. MA-Thesis. University of Oslo.

Mikkelsen, Arvid (2005): Det Tause Folkets Stille Død?: En Reise i Kvenenes Verden i Fakta og Følelser. Vadsø: Iđut.

Niemi, Einar (1991): Kven - et omdiskutert begrep. Varanger Årbok. Alta

Nygaard, Vigdis/Bro, Jørgen (2015): Årsaker til frafall fra finsk som andrespråk. RAPPORT 14/2015.

Pietikäinen, Sari/Huss, Leena/Laihiala-Kankainen, Sirkka/Aikio-Puoskari, Ulla/Lane, Pia Regulating multilingualism. in the North Calotte: the case of Kven, Meänkieli and Sámi languages. Acta Borealia, 27:1, 1-23.

Røyneland, Unn (2009): Dialects in Norway: catching up with the rest of Europe? International Journal of the Sociology of Language, 196/197, 7-31.

Saressalo, Lasse (1998): Grunnlaget for en egen kvensk etnisistet i Nord-Norge med bakgrunn i den kvenske minoritetens språk, historie og kultur. In: Guttormsen, Helge (Ed.): Kvenenes Historie og Kultur. Seminarrapport. Nord-Troms historielag.

Seppola, Bjørnar (1996): Norsk Skolepolitikk overfor Kvenene 1720-1996. MA thesis, University of Tromsø.

Trudgill, Peter (2002): Sociolinguistic Variation And Change. Edinburgh: Edinburgh University Press.

Vikør, Lars (2007): Språkplanlegging. Prinsipp og praksis. Oslo: Novus Forlag.

Woolgar, Steve (1991): Configuring the user: The case of usability trials. In: Law, John (Ed.) $A$ sociology of monsters - essays on power, technology and domination. London: Routledge. 